\title{
INTERNATIONAL COPYRIGHT PROTECTION AND THE UNITED STATES: THE IMPACT OF THE UNESCO UNIVERSAL COPYRIGHT CONVENTION ON EXISTING LAW
}

THROUGH its copyright laws, nearly every nation ${ }^{1}$ gives its own nationals who create literary or artistic works power to prevent commercial use of their creations without their consent. Within his own nation the artist, or his transferee, can determine on what terms his work-such as books, music, plays, paintings, and motion pictures-shall be produced and who shall produce it. ${ }^{3}$ Although this may tend to restrict dissemination of authors' works, most countries feel that copyright protection encourages literary and artistic production to an extent which justifies its existence."

A different situation arises, however, when an author in country $A$ (the country of first publication or origin) seeks the power to control reproduction or translation of his work in country $B$ (the "protecting" country). For several reasons country $B$ may not protect foreign authors." Country $B$ may

1. Afghanistan, Ethiopia, Iraq, Mongolia, Nepal, Saudi Arabia, and Yemen provide no copyright protection at all. 4 UNEsco Copyrigni BuLz 63-102 (No. 3 1951). For a list of nations granting copyright to their own nationals, sce 2 id. at 12-16 (No. 2-3 1949). For a comprehensive survey of the domestic and international copyright laws of the various nations, see 4 id. at 104-260 (No. 1-2 1951) (Europe); 4 id. at 63-102 (No.3 1951) (Africa; Asia); 4 id. at 13-95 (No. 4 1951) (South America; Mexico) ; 5 id. $7 \mathrm{~s}-113$ (No. 1 1952) (United States; Central America).

2. All nations, in substance, allow transfer of copyright. Sce 2 id. at 104-111 (No. 2-3 1949). But some nations give the author a ston-transferable right to objcet to mutilation of his work which reflects adversely on his reputation. See 1. 1076 infra.

3. Procuring the author's consent to reproduction usually involves remunerating him, and this "right" to be paid is the author's bread and butter. A complete tabulation of the rights granted to an author by the various nations, describing the types of vorks protected and the author's power over various uses, with citations to relevant statutor: provisions, may be found in 2 UNesco Coprright Bru. 18-143 (No. 2-3 1949); 2 id. at 30-155 (No. 4 1949). For United States provisions, see 17 U.S.C. $\$ 1$ (Supp. 1952); Howell, The CopYright Law 11-26, 120-53 (3d ed. 1952) (hereinafter cited as Howzu).

4. Putnaat, The Question of Copyrignt 1-7, 35-95, 364-S (1891); Chafee, Feficetion on Copyright Law, 45 CoL. L. Rev. 503, 506-15 (1945); Evans, Copyright and the Public Interest, 2 Unesco Copyright Bull 2 (No. 1 1949). Sce also Piorzheimer, Copyright Reforn and the Duffy Bill, 47 YALE L.J. 433 (1938); Warner, US. Copyright Act: Anti-ilionopoly Provisions Necd Some Rerision, 34 A.B.A.J. 459, $461-3$ (1948); H.R. REP. No. 2222, 60th Cong., 2d Sess. 4 (1909). For an excellent critical and philosophical treatment of copyright, see Chaffee, supro, at 503, 719.

5. In addition to the nations listed in note 1 supra, Altania, Ehutan, Burma, Hashemite Jordan, Indonesia, Korea, Kuwait, Oman. San Mrarino, and U.S.S.R. seem t, grant no protection to foreign works. See chart, 2 Lisesco Curragnr Ilch 32 (No. a 1949). For a wry comment on protection of foreign works in the Suvis Lniun, sS. Chafee, supra note 4 , at 523 . 
freely enjoy a wealth of art created in other countries while contributing little copyrightable material to the world. ${ }^{6}$ Or its printers, in order to maintain a monopoly over the printing of matter distributed domestically, may try to prevent protection of material printed abroad. ${ }^{7}$ Such attitudes, in turn, can prejudice the rights of country $B$ 's nationals in country $A ; A$ may be reluctant to give copyright protection to authors from nations which make it difficult for $A$ 's nationals to procure protection abroad. ${ }^{8}$

To curtail mutual piracy of foreign. literary works, most nations early attempted to achieve international control through bilateral treaties. ${ }^{0}$ These treaties, many of which are still in force, ${ }^{10}$ obligate country $B$ to honor copyrights from country $A$. But the bilateral approach from the start spurned uniformity and engendered confusion. ${ }^{11}$ Hence, nations sought instead to assure copyright protection by multilateral agreement. During the last quarter of the nineteenth century, European nations and a few others organized the International Copyright Union, generally known as the "Berne Union."12

6. China typifies this position: her literary production is probably negligible; at least statistics on her literary production are not available. UNESCO, STATISTICAL REPokT oN Book Production 1937-1950 (1952). And China pirates foreign works. Hearings before Subcommittee No. 3 of the Committee on the Judiciary on H.R. 4059, 82d Cong., 2d Sess. 209 (1952). Her international copyright obligations are confined to an article of a 1903 Supplementary Treaty of Commerce with Japan, the present applicability of which appears doubtful, 2 Unesco Copyrigrt Bull. 52 (No. 4 1949), and article IX of the 1946 Treaty of Friendship, Commerce and Navigation with the United States, U.S. Treaty SER., No. 1871 (Dep't State 1946), 63 STAT. 1300, 130\&-9 (1949). The latter agreement merely allows nationals of either country to comply with the copyriglit lan of the other. Ibid. For the extent and nature of protection in China, see 4 UNesco COPYRIGHT BULl. 70-72 (No. 3 1951).

7. The United States printing trades have taken this position. See pp. 1069-70 infra.

8. For an example of this kind of retaliation, see pp. 1079-80 infra.

9. 1 Ladas, Tae International Protection of Literary and Artistic Phoperty $44-67$ (1938) (hereinafter cited as LADAS). But see Finkelstein, Book Review, 48 Yalv L.J. 712 (1939); Chafee, Book Review, 52 HARv. L. Rev. 1378 (1939), both criticizing Ladas' treatment of copyright theory.

10. See, e.g., the present bilateral relations of France, 2 UNEsco Copyucur BuLl. 64-72 (No. 4 1949). For a general treatment of modern bilateral arrangements, see $2 i d$ at 30-155; 1 LADAS 150-79.

11. 1 LADAS 50-67. Also see list of United States copyright relations following 17 U.S.C.A. \& 9 (Supp. 1952).

12. The official name is: L'Union internationale pour la protection des ocuvres litteraires et artistiques. A history of the numerous preparatory meetings and of the final conference called in 1886 for the signing of the treaty, plus a list of the countries participating, may be found in 1 LADAS 71-83. For a general discussion of the International Copyright Union see DeWolf, International Copyright Union, $18 \mathrm{~J}$. PAT. OFF. Soc'y 33 (1936); Solberg, The International Copyright Union, 36 YALE L.J. 68 (1926); Solberg, Copyright Law Reform, 35 Yale L.J. 48, 66-8 (1925). See also, Copnater \& SkONE JAMES, LAW of Copyright 268-87 (8th ed. 1948) (hereinafter cited as Copinger); Unwin, The Truth About Publishing 264-6 (4th ed. 1946), Kilroe, International. Copyright 1-36 (1944), Bowker, Copyright: Its History and Its LAW 311-40 (1912), LANCEFietd, Notes on Copyright fill 153-206 (1896). 
Acceptance of Berne. however, has been confined largely to Europe. The United States ${ }^{13}$ and others in the Western Hemisphere ${ }^{15}$ have remained aloof.

In the hope of instituting a system of international copyright control which would be acceptable to Berne members, to the United States, and to Latin America, the United Nations Educational, Scientific and Cultural Organization (UNESCo) began in 1947 to draft a universal copyright convention. ${ }^{\text {to }}$ Recent submission of the final draft of this document ${ }^{16}$ poses anew the general problem of effective international protection, and in particular the question of United States participation. ${ }^{17}$

\section{United States Protection of Foreign Works}

The United States currently grants protection to only a limited number of foreign works. This country has never joined the Berne Union. ${ }^{18}$ America

13. See Brown, The Role of the United States in Relation to the Internaliosal Copyright Union in Reccut Years, 34 J. PAT. OFF. Soc'y 141, 200 (1952); p. 1058 injre.

14. Of the Western Hemisphere nations only Brazil (1922), Canada (18\$7), and Haiti (1SS7) joined the Berne Union, 1 LApas 121, and Haiti renounced the treaty in 1943, 2 Unesco Copyright Bull. 84 (No. +1949 ). Dates in parentheses are those of ratification. For discussion of copyright protection among Ameriean states, see PAz: Axrerican Union, Copyright Protection in the Asrerichs, Pts. IV and $V$ (Law and Treaty Ser. No. 33, 2d ed. 1950) (hereinafter cited as Pecrecrio: n tae Azsensess); Note, Inter-American Copyright Contention, $60 \mathrm{HARr}$. L. Rar. 1329 (1947); Hottse of Delegates: Proceedings, 33 A.B.A.J. 390, 399-400 (1947).

15. Resolution 2.4.1 of the General Conference of Uxesco at Mexico City in 1947 stated: "Unesco shall, with all possible speed and with due regard to existing agreements, consider the problem of improving Copyright on a world-wide basis." Qunted in 1 Unesco Copyright But. 2 (No. 1 1948). See Kuhn, The IForl of L'icsio on Copyright, 43 Ax. J. INTL L. 343 (1949). A comparative study of copyright laws was carried on in 1948, followed by meetings of committees of experts. The Third Committee of Experts, meeting in Washington, D.C., in 1950, debated extensively the substantive provisions which a new convention should contain. For a summary record of this meeting sse 3 Unesco Copyright Bull. 3-99 (No. 3-4 1950). A final draft was completed in Paris in 1951. $4 \mathrm{id}$. at 3-30 (No. 3 1951) (volumes $1+4$ of the Uxestio Cupvisur LurLusm: are devoted to presenting in detail the information collected by the Copyright Division of Unesco). See also U.N. Universal Declarition of Hussin Kiguts, art. 27, ff 2: "Everyone has the right to the protection of the moral and material interests resulting from any scientific, literary or artistic production of which he is the author."

16. Thirty-six nations, including the United States, signed the Usesco Universal Copyright Convention at an Intergovernmental Copyright Conference in Geneva, Switzerland, in September, 1952. 5 Unesco Copynight BurL 27-9 (No. 3-t 1052). Four countries-Belgium, Israel, Japan, and Peru-signed after the Conference had ended. For a complete list, see authorities cited in note 161 infra. But the Convention will not go into effect until ratified. UNIVERsal COPYRIGHT CONvENTION, art. IX (hereinaiter cited as UCC).

17. See p. 1083 infra. Enabling legislation will soun be presented to the Congress. Communication to the Yale Law Journal from Arthur Fisher, Register of Copyrights, dated February 26, 1953, in Yale Law Library.

18. See text at note 13 supra. 
was originally content to pirate literary works of other nations, especially England's. ${ }^{19}$ Under the federal copyright statute of 1790,20 a non-resident alien could not procure copyright here..1 An 1891 amendment, however, forsook the policy of piracy by enabling foreigners to get American copyright, ${ }^{22}$ and the substance of that legislation persists to the present. ${ }^{23}$

\section{Requirements for Acquiring American Copyright}

Foreigners can currently obtain copyright in the United States only if certain conditions are met. First, the President must proclaim that the foreign author's country grants American authors the same protection it gives its own nationals. ${ }^{24}$ Such proclamations have issued to thirty-six nations. ${ }^{25}$ Secondly,

19. In general, see Bowker, COPYRIGHT: ITS HIstory AND ITS LAw 341-72 (1912); Copinger 291; Report of the British Commission of 1878, in The Question of Corrright 267-71 (Putnam ed. 1891) ; Matthews, Cheap Books aNd Good Books (1888); Putnam, International Copyright (1879); White, The American View of tul COPYRIGHT QUestion (1880). For a British view of American piracy see Bolln, Tur: Question of UnReciprocated Foreign Copyright (1851). For an early publisher's defense of international copyright anarchy, see Carey, The InTERnational CopYrugut Question Considered (1872); Carey, Letters on International Copyrugut (1853). And see, Morgan, Anglo-American International Copyright (1879).

20. Copyright Act of 1790, 1 Stat. 124 (1790).

21. " $[N]$ othing in this act shall be construed to extend to prohibit the importation or vending, reprinting or publishing within the United States, of any map, chart, book or books, written, printed, or published by any person not a citizen of the United States, in foreign parts or places without the jurisdiction of the United States." Copyright Act of $1790, \S 5,1$ STAT. 125 (1790).

22. 26 Stat. 1106-7 (1891) ; see H.R. Rep. No. 2401, 51st Cong., 1st Sess. (1890).

23. See 17 U.S.C. \& 9 (Supp. 1952).

24. Ibid. A citizen of an unproclaimed country cannot, by assigning his reproduction rights to a national of a proclaimed country, acquire protection in the United States. Bong v. Alfred S. Campbell Art Co., 155 Fed. 116 (2d Cir. 1907), aff'd, 214 U.S. 236 (1909). But the Second Circuit has held that the American assignee of Adolf Hitler, who had no citizenship, had acquired a valid United States copyright in Mcin Kampf. Houghton Miffin Co. v. Stackpole Sons, 104 F.2d 306 (2d Cir.), cert. denied, 308 U.S. 597 (1939). For discussion of the Houghton Miffin case see Breathitt, Copyright Protection of Alichs and Stateless Persons, 41 Kx. L.J. 302 (1953); Dawson, Hitler and the Copyrights of Stateless Persons, 21 PA. B.A.Q. 26 (1949) ; Smith, The Kampf about "Mcin Kampf," 19 B.U.L. Rev. 633 (1939); Note, 49 Yale L.J. 132 (1939); Note, 13 So. Calm. L. Rev. 356 (1940).

25. Argentina, Australia, Austria, Belgium, Canada, Chile, Costa Rica, Cuba, Czechoslovakia, Danzig, Denmark, Finland, France, Germany, Great Britain and possessions, Greece, Hungary, Ireland, Israel, Italy, Luxembourg, Mexico, Netherlands and possessions, New Zealand, Norway, Palestine (excluding Trans-Jordan), Philippines, Poland, Portugal, Rumania, Spain, Sweden, Switzerland, Tunisia, and Union of South Africa. 17 U.S.C. $\S 9$ (1952). The most recent proclaimed nation is the Principality of Monaco. See 1 U.S. Code Congs. \& Admin. News, 82d Cong., 2d Sess, 1001 (1952). By proclamation, bilateral treaty, or multilateral convention, the United States has copyright relations with a total of fifty-four nations. Ibid. 
a foreign author must comply with the formalities imposed on Americans. ${ }^{20}$ Any publication of the work must bear notice of copyright, its date, and the name of its proprietor. ${ }^{27}$ The author must, on demand of the Register of Copyrights, deposit two copies of the work-or one copy and four dollars $;^{\wedge 3}$ and he must register his claim to protection. ${ }^{20}$ An author can copyright a worls not reproduced for sale, such as a motion picture, simply by filing with the Copyright Office a registration containing a description of the work: ${ }^{20}$

The Manufacturing Clause. The most serious obstacle confronting foreign authors who seek American copyright is the statutory requirement that, in order to be protected in the United States, all books or periodicals in the English language "shall be printed from type set within the limits of the United States."31 Enacted in 1891,"32 when the printing trades may have needed shelter from foreign competition at the expense of English authors, 33 the manufacturing clause has served to deny American copyright to all but the best-known foreign authors writing in English.

The manufacturing clause presents no problem to an English author, such as Winston Churchill, who writes a "sure" best seller." Regardless of the statutory requirement, he or his publisher will make arrangements with an American publisher to have his book printed here, thus reaping the advantages of an American distribution network and large scale press runs to which European equipment is not adapted. ${ }^{35}$ Publishers commonly adopt this practice. $^{36}$

26. 17 U.S.C. $\$ 9$ (Supp. 1952).

27. 17 U.S.C. $\$ \$ 10,19$ (Supp. 1952). But see Katz, Is Notice of Copyright Necessary in Works Published Abroad?-A Qucry and a Qtandary, [1953] Wasa. U.L.Q. 55; Note, 22 N.Y.U.L.Q. REv. 105 (1947).

28. 17 U.S.C. $\S \S 13,14,215$ (Supp. 1952).

29. 17 U.S.C. $\$ 13$ (Supp. 1952). 37 Cone Fen. REGs. $\$ 203.1$ (b) (1949). Also sRe HoweIl 85-6.

30. 17 U.S.C. § 12 (Supp. 1952).

31. 17 U.S.C. $\$ 16$ (Supp. 1952). For discussion of the statute, see Breathitt, Cosyright Protection of Aliens and Stateless Persons, $41 \mathrm{Kr}$. L.J. 302 (1953); Shriver, Notcs on the Law of Copyright and Importation of Books, 31 LAw Liv. J. 127 (1938); Solbarg, The New Copyright Bill, 15 Notre Dane Law. 123, 130-40 (1940); Nate, Rclosation of the Manufacturing Requirement for Forcign Works, 35 Coss. L.Q. 452 (1950).

32. 26 STAT. 1107 (1891).

33. See H.R. REP. No. 2401, 51st Cong., 1st Sess. 1-2 (1890); Solbarg, The International Copyright Union, 36 YALE L.J. 68, 104 (1926) ; Ashford, The Compalsory Monusfacturiing Provisions in Ascap, Fourtr Coprright LAw Sympusiugs 52-7 (1952). American publishers very shortly abandoned their earlier support of the manufacturing clause. See statement of George H. Putnam quoted in Ashford, sulra, at 54-5.

34. The manufacturing clause also applies to works translated into English and printed abroad. See 17 U.S.C. $\$ 16$ (Supp. 1952).

35. See Hearings, supra note 6 , at 27; Chafee, suspra note 4, at 523-6.

36. Heariangs, supra note 6 , at 27. 
The one who suffers most from the manufacturing requirement is the English-writing alien who cannot predict his American market. Since American publishers are loath to print an edition of less than 8,000 copies, ${ }^{37}$ an Englishman cannot use a small American printing to test the market here by taking advantage of the American distributing network. Under an amendment to the manufacturing clause, ${ }^{38}$ however, a foreign author has six months after a publication abroad in which to acquire a temporary American copyright on the material printed there. Known as ad interim copyright, this protection lasts for five years. During that time the author may import 1,500 protected copies of the work into the United States. ${ }^{39}$ But, if at the end of five years he wants to retain American copyright, he must have an edition printed in this country. ${ }^{40}$

Ad irterim protection is not all that a foreign author might desire. If his work meets with little initial success, the foreign author may not find it feasible to engineer an American printing during the ad interim period. Should he later write a best seller, the demand for his earlier book might skyrocket. But since the author could no longer copyright the earlier work in the United States, ${ }^{41}$ American publishers could reproduce it without paying royalties. The problem is aggravated by the fact that denying copyright in a book also precludes the foreign author from deriving any benefit from motion picture, radio, or dramatic adaptation of his work in the United States. Thus, without an American edition, the English-writing author risks piracy which may cost him the lion's share of his potential reward.

\section{Equality of Substantive Protection}

Once a foreign author obtains United States copyright, however, his substantive protection is the same as that of Americans. He acquires the exclusive right to vend, copy, or translate his work, or to perform it publicly for profit if a musical work. ${ }^{42}$ In addition, a copyright proprietor can enjoin unauthorized use of his work and recover minimum statutory damages therefore. ${ }^{48}$ This protection lasts twenty-eight years, renewable for an identical term.44

37. Id. at 159 .

38. 35 Stat. 1080 (1909), as amended, 17 U.S.C. $\& 22$ (Supp. 1952).

39. Ibid. For a discussion of the most recent changes in ad interim protection, raising the import limit from 500 to 1500 copies and increasing the period for registration from 60 days to six months, see Hearings before Committec on the Judiciary on H.R. 2285, 81st Cong., 1st Sess. (1949).

40. 17 U.S.C. \& 23 (Supp. 1952).

41. 17 U.S.C. \& 22 (Supp. 1952).

42. This list of rights is not exhaustive. For a complete list see 17 U.S.C. $\$ 1$ (Supp. 1952). For a short summary of authors' rights, see Schulman, Authors' Rights in Federal Bar Ass'n, 7 Copyright Problens ANalyzed 19-30 (1952).

43. 17 U.S.C. $\S 101$ (Supp. 1952).

44. 17 U.S.C. $\$ 24$ (Supp. 1952). See Kupferman, Renezwal of Copyright, 44 Cow L. Rev. 712 (1944). 


\section{Inter-American Agreenents}

The requirements of proclamation, compliance with formalities, and domestic manufacture do not apply to nationals of fourteen Latin American nations who joined with the United States in the Buenos Aires Copyright Convention of 1910.45 This treaty, ${ }^{40}$ closed to non-American countries, specifies that an author must obtain copyright in the country of first publication before other nations are obligated to grant protection. is Each copy of the work must contain notice that rights have been reserved. ${ }^{40}$

The treaty, however, does not assure United States creators of complete protection south of the border, nor does it confer upon their Latin American brethren absolute control over works circulated in the United States. Administrative and tariff restrictions in Latin America, 50 combined with narrow judicial interpretation in the United States, 10 may have undermined protection in Latin America.52 These restrictions curtail imports of American books and periodicals printed in the national language-material which would compete with the domestic publishing industry. And despite the provisions of the

45. 17 U.S.C. $\$ 9$ (b) (Supp. 1952).

46. U.S. TREATY SER., No. 593 (Dep't State 1910), 38 Stat. 1785 (1914). The following nations have ratified the treaty: Argentina, Brazil, Colombia, Costa Rica, Dominican Republic, Ecuador, Guatemala, Haiti, Honduras, Nicaragua, Panama, Paraguay, Peru, United States, and Uruguay. 2 Unesco Cuprkignt Brzo 144 (No. 4 1949). Mexico has recently ratified the Convention, but has not yet notified the Pan-American Union officially. Communication to the Yale Law Jocrasa from Manuel Canyes, Chief, Division of Law and Treaties, Organization of American States, dated March 30, 1953, in Yale Law Library. See also, Ladas, Inter-American Copyrigltt, 7 U. of PIrT. L. Rev. 283 (1941) ; Sanders, The Protection of Intcllectual Property of American Citizcus in Latin America, 139 Publishers WeekLy 2456 (1941); Protectron int the Asfenvens 11-22.

47. Buenos Ames Conventiox of 1910, Preamble. The full text of this Convention is found in Protection In the Asiericas 199 et seq.

4S. Buevos Aires Conventron of 1910, art. 3. The rights granted to an author under this treaty are "the exclusive power of disposing of [his copyrighted worls], of publishing, assigning, translating or authorizing its translation and reproducing it in any form whether wholly or in part." Id. art. 4.

49. Id. art. 3.

50. For a summary of these restrictions, see Hcarings, sipra note 6 , at $38,150,213$; Warner, The Unesco Unizersal Copyright Coniention, [1952] WIs. L. Rex. 493, 493; Sanders, supra note 46; Protrction ix the Amesicis 107-110, 174-5.

51. Since courts have construed article 4 , note 48 supra, as not covering mechanical reproduction rights, nationals of Buenos Aires treaty nations cannot get royalties from the use of their copyrighted music on phonograph records. Todamerica Mlusica v. Radio Corporation of America, 171 F.2d 369 (2d Cir. 1948) ; Portuondo v. Columbia Phonograph Co., S1 F. Supp. 355 (S.D.N.Y. 1937). And see 29 OPS. ATt'y Gesi. 64 (1911) for the origin of this limiting interpretation of the Copyright Act of 1909, 35 STAr. 1075 (1909), 17 U.S.C. $\$ 1$ (e) (Supp. 1952).

52. See Hearings beforc Scnate Committec on Forcign Relations on Exccustize $E$, 73d Congress, 77th Cong., 1st Sess. 38-40, 65, 78-9, 87-9 (1941); Statement of Edwin P. Kilroe, Hearings before Senate Committee on Foreign Relations on Exccutize E, 73d Congress, 75th Cong., 1st Sess. 2-3 (1937). 
treaty, ${ }^{53}$ some countries impose deposit and filing fees on foreign authors. ${ }^{54}$ Conversely, United States protection against unauthorized American recordings of foreign music requires a Presidential proclamation finding that the composer's nation grants mechanical reproduction rights to Americans. ${ }^{56}$ The treaty does not supersede this special requirement. .0 And such proclamations have issued only to Argentina, ${ }^{57} \mathrm{Cuba},{ }^{58}$ and $\mathrm{Chil}^{50}$ among the Latin American nations, even though the recording right is one of the most valuable the Latin American can have today. ${ }^{00}$

The Inter-American Convention of $1946^{\circ 1}$ attempted to strengthen the Buenos Aires treaty. Ten nations, including Brazil and Mexico, have adopted the revision. ${ }^{62}$ But the United States has taken no action toward ratification, ${ }^{03}$ presumably because she objects to the broad protection given to an author's reputation, ${ }^{64}$ the agreement's retroactive application, ${ }^{05}$ and provisions which make it mandatory to enjoin publication of infringing works. ${ }^{60}$

53. Buenos Atres Convention of 1910, art. 3: "The acknowledgement of a copyright obtained in one state in conformity with its laws shall produce its effects of full right in all other states, without the necessity of complying with any other formality, provided always there shall appear in the work a statement that indicates thel reservation of the property right."

54. 4 Unesco Copyright Bull. 12-52 (No. 4 1951); Sanders, supra note 46.

55. 17 U.S.C. § 1 (e) (Supp. 1952). And see note 51 supra.

56. See note 51 silpra.

57. 49 STAT. 3413 (1913), 17 U.S.C.A. $\& 9$ (1952).

58. 37 STAT. 1721 (1911), 17 U.S.C.A. \& 9 (1952).

59. 44 STAT. 2590 (1925), 17 U.S.C.A. \& 9 (1952).

60. Communication to the Yale Law Journal, from Herman Finkelstein, General Attorney, ASCAP, dated March 31, 1953, in Yale Law Library.

61. For the text of this Convention see 1 Unesco Copyrigert Bull. 94 (No. 2 1948). And see Pan-American Union, Handbook for Delegates to Inter-American Conference of Experts on Copyright (1946); Pan-American Union, Proceedings of tile

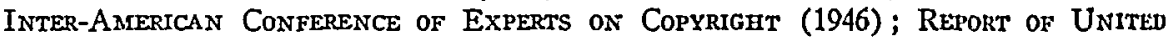
States Delegate to Inter-American Conference of Experts on Copyrugit, U.S. Conf. SER. No. 99 (Dep't State 1947). Also see Rea, Some Legal Aspects of the PanAmerican Copyright Convention of 1946, 4 WASH. \& LEE L. REv. 10 (1946); Comment, The Inter-American Copyright Convention: Its Place in United States Copyright Lazu, 60 HARv. L. Rev. 1329 (1947).

62. Bolivia, Brazil, Costa Rica, Dominican Republic, Ecuador, Guatemala, Honduras, Mexico, Nicaragua, and Paraguay have ratified this treaty. Communication from Manuel Canyes, supra note 46.

63. The treaty was presented to the Senate by President Truman, 93 Cong. Rec. 9121 (1947), but the treaty, Executive HH, 80th Cong., 1st Sess., is still in the hands of the Senate Foreign Relations Committee. CCH Cong. INDEx, 83D ConG. 7004 (1953).

64. Even though the Convention makes this "moral" right alienable. INTEn-AMEnuCAN ConventTon of 1946, art. XI.

65. If a work is in the public domain of the protecting country, protection will be restored unless some person in the protecting country has acquired a vested right in that work before ratification. Id. art. XVII(2).

66. Id. art. XIII. In the United States, the injunctive remedy is permissive, 17 U.S.C. $\S 112$ (Supp. 1952), as is seizure of infringing works, 17 U.S.C. $\S 101$ (d) (Supp. 1952). 


\section{International Protection in Europe: The Berne Union}

While the United States pursued a nationalistic policy, Europenn nations formed the Berne Union in 1886. 07 This multipartite organization granted any person publishing an original literary or artistic work in a nation belonging to the Union protection against unauthorized reproduction in other member nations. ${ }^{68}$ Despite subsequent revisions-in $1908,{ }^{, 9} 1928,{ }^{70}$ and $1948^{71}$-the Union has retained this concept. ${ }^{22}$ And the Union now has forty-three members, representing all of Europe, much of the non-American world, Canada, and Brazil.73

67. The following nations ratified the Berne Convention of 1886 (date of ratification is shown in parenthesis): Australia (1887); Belgium (1887); Canada (1887); Denmark (1903) ; France (1887); Germany (1887); Great Britain (1887); Haiti (1887) (but see note 14 supra); India (1887); Irish Free State (1887); Italy (1887); Japan (1899); Luxembourg (18S\$); Mionaco (18S9); New Zealand (1887); Norway (1886); Spain (1887) ; Sweden (1904); Switzerland (1ES7); Tunis (18S7); Union of South Africa (1887). 1 LADAS 121-2. There were numerous conferences prior to 1886, but their unofficial character prevented binding action. The first official conference met in Berne in ISS4 to prepare a draft convention. Fourteen countries, most of them European, participated. A second official meeting at Berne in 1885 made slight modifications of the earlier draft. And the Convention was finally signed at Berne in 1886. For a detailed report of these conferences, with citations to the original documents, sce 1 id. at 71-83.

68. Berse Convention of $18 \$ 6$ ari $2, \S 1$. The complete text of the Convention, in French and English, is reproduced in 2 LADAs 1123-34.

69. The Berne Convention was revised at Berlin in 1908. 1 id. at 89-94. For the text of this revision, see 2 id. at 1141-54. For comments on the Berlin Revision, spe Bowker, Copyright: Its History and Its Law 326-30 (1912); Comtignt Office, Report of the Unted States Dezegate to the Benum Confene:tes (Bull. No. 13 1908); 1 LADAS 89-94.

70. For English and French texts of the $192 \mathrm{~S}$ Revision undertalien at Rome, see 2 id. at 1156-74. For comments on this revision, see Kilroe, Adheresec of the linitcd States to the Berne Conzention as Modificd at Rome, 9 Copyerght Matrarne (1936) (CoryRIGHT MATERIAL is a collection of miscellaneous literature on copyright, presented to Yale Law Library by Edwin P. Kilroe); Minutes and Doetments of the Rome Conference, 1928, id. at 18-19; Solberg, The Intemational Copyright Union, 36 YALE L.J. 6S, 84S (1926).

71. The latest revision of the Convention took place at Brussels. For the text see Howerl 311-25. For discussion see Platsant, Reforter-Gentezat, Gerieral Rerort o: the Work of the Diplomatic Conference, för tee Revision of the Berite Co:me:Tion (194S) (translated from the French by the U.S. Copyright Office); U.S. STATE Dep't, Report of the Untred States Obsester Dezesations to the Istrasiational. Conference for Reuision of the Berne Convention (1949); Chedial, The Progressive Development of World Copyright Law', 42 A3r. J. INr'L L. 797 (1948); Fisher, The 1948 Revision of the Berne Conzention, $10 \mathrm{FED}$. Cossus. B.J. 53 (1949); Foster, Intcrnational Copyright Protection, 3 So. CAr. L.Q. 60 (1950); The Recision of the Berne Conzention in Brussels, 1 Unesco Copyngrat Bull 10 (No. 2 194S).

72. See BerLin Revision art. 4, § 1 (1908); Rose Rerision art. 4(1) (1923); BRUSSELS REvision art. 4(1) (1948).

73. The following countries are members of the Berne Union: Australia, Austria, Belgium, Brazil, Bulgaria, Canada, Czechoslovakia, Denmark, Finland, France, Germany, Great Britain and Northern Ireland, Greece, Hungary, Iceland, India, Irish Free State, 
From the outset, conflicting forces moulded the scope and character of Berne protection. Some members were reluctant to favor foreign authors over native creators, and hence sought "national treatment": they wished to confine the protection given the foriegn author to that which he would receive if he published initially in the protecting nation. ${ }^{74}$ On the other hand, there was a desire to abandon national treatment in some fields in favor of uniformity, particularly where member nations required foreigners to comply with formalities peculiarly designed for domestic purposes. ${ }^{75}$ The Union which the interplay of these forces produced can be analyzed in terms of the following standards: what is protected, through what formalities, for how long. In addition, there is the question of adherence: to what extent members may accept some provisions and reject others.

\section{Scope of Protection}

Works protected. Under bi-national arrangements prior to Berne, country $B$ would protect a work from country $A$ only if country $B$ 's domestic legislation protected similar works produced by its own nationals. ${ }^{70}$ But Berne continually, though gradually, supplanted domestic law with an international code; its copyright now embraces many classes of material not previously protected by domestic legislation. ${ }^{77}$ The original Berne Convention extended uniform protection only to the most prevalent literary forms. ${ }^{78}$ After the 1908 Berlin Revision, however, protected works, whether published or unpublished, included:

"[A]11 productions in the literary, scientific, or artistic domain, whatever the mode or form of reproduction, such as: books, pamphlets and other writings; dramatic or dramatico-musical works ; choreographic works and pantomimes, the stage directions of which are fixed in writing or otherwise; musical compositions with or without words; drawings, paintings; works of architecture and sculpture; engravings and lithographs; illustrations; geographical charts; plans, sketches and plastic works relating to geography, topography, architecture or the sciences.

"Translations, adaptations, arrangements of music and other reproductions transformed from a literary or artistic work, as well as

Israel, Italy, Japan, Lebanon, Liechtenstein, Luxembourg, Morocco, Monaco, Netherlands, New Zealand, Norway, Pakistan, Philippines, Poland, Portugal, Rumania, Thailand, Spain, Sweden, Switzerland, Syria, Tunisia, Turkey, Union of South Africa, Vatican City, Yugoslavia. DRoIT D'AUTEUR 1-5 (Jan. 15, 1953). Also see communication to the Yale Law Jolinnal from Dr. Bénigne Mentha, Director of the Berne Union, dated April 20, 1953, in Yale Law Library (translated from the French by Miss Maric McMahon).

74. Copinger 270; 1 LAdas 83-6.

75. See authorities cited note 74 sipra.

76. 1 LADAS 53-4.

77. See 1 id. at 33, 53-5.

78. Berne Convention of 1886 art. IV. 
compilations from different works, are protected as original works without prejudice to the rights of the author of the original work." ${ }^{\text {" }}$

This list was expanded in 1928 to include so-called "oral" works-lectures, sermons, and non-political speeches ${ }^{80}$ and the 1948 Brussels Revision added photographic works. ${ }^{81}$

The Convention applied uniformly to all of the above worls which had. at the time of ratification by the protecting country, a valid copyright in the country where the work was first published. ${ }^{82}$ If the work was then in the public domain in the protecting nation, copyright was inaugurated. 83 After the 1908 Berlin Revision, signatory countries granted protection even if the formalities necessary for copyright in the country of origin were not met. ${ }^{81}$ Thus, if a French author published a book in 1905 and did not acquire copyright in France, he had no protection in Berne nations. But because of the 1908 amendment he would thereafter be protected in member nations, even though he still did not have French copyright. If, however, French protection had lapsed through expiration of the tcrm of copyright, the author could acquire no rights in member nations. 85

Substantive rights protected. The author's substantive rights in protected works are also, broadly speaking, uniform. Prior to 1908, domestic law set the limits of protection. ${ }^{88}$ But now the Convention guarantees to the author the exclusive power to print, copy, sell, or perform his work. 87 It also preserves the author's right to translate his works ${ }^{88}-2$ valuable commodity in the world market. Under the 1886 Convention, the right to translate remained in force for only ten years following the original publication. ${ }^{80}$ Although this protection in many cases surpassed that which member nations had previously bestowed upon foreign authors, ${ }^{90}$ members later thought the ten-year period

79. BERLIN REVISION of 1908 art. 2.

80. RoNie Revision of 1928 art. 2(1).

81. This document extended code treatment to "photographic works and works produced by a process analogous to photography." Brissers Revision of 1948 art. 2(1).

82. Id. art. 18, $\S 1$.

83. Berne Convention of 1836 art. XIV; Final Protocol to the Berse, Coi:vention If 4 in 2 Ladas 1132; Additional Act of 1896 art. II(2) in 2 Lados 1138.

84. Berlin Revision of 1908 arts. 4, 18. Also see 1 Lapis 348-50.

85. Brusseus Revision of 1948 art. 18, $\$ 2 ; 1$ Lanas 349-50. On the general application of the retroactivity clause, see 1 id. at 343-59.

86. Berne Contention of 1886 art. II, $\$ 1$. And see 1 Lab.1S 363-7.

87. BRUSSEIS Reviston of 1948 arts. S-14.

SS. Id. art. S. The author of the original has the exclusive right to translate or authorize another to translate. Ibid. In addition, the translator, whether the author or his assignee, may copyright the translation once it is made. See text at note 79 supro.

89. Berne Convention of 1886 art. V, § 1. And see 1 Lavis 84, 371-3.

90. $1 \mathrm{id}$. at $38-40,58-61$. For example, in Germany, Austria, and Hungary no translation right existed for foreign authors unless they explicitly reserved the right to translate, and published a translation in the national language within one year from the end of the calendar year during which the original work appeared. 1 id. at $3 \%$. 
inadequate; translation was a widespread form of piracy. ${ }^{91}$ Since 1908, the right to translate has been treated on a par with the author's other rights in the reproduction of his work. ${ }^{92}$

In addition, the Convention currently assures the author of control over radio, phonograph, and motion picture adaptations. ${ }^{93}$ Berne grants him during his lifetime a non-transferable right "to object to every deformation, mutilation or other modification of the ... work, which may be prejudicial to his honor or . . . reputation." ${ }^{\text {94 }}$ This "moral rights" clause,, adopted in $1928,{ }^{96}$ had appeared in the domestic law of many Berne nations. ${ }^{07}$ It strengthened the position of authors bargaining over rights to radio or movie reproduction, the two major channels of adaptation. ${ }^{98}$

\section{Formalities}

Formalities necessary to invoke protection outside the country of first publication also received code treatment. Before 1908, the author first had to obtain formal copyright in the country of origin. ${ }^{09}$ Currently mere publication -issue of a work for public consumption 100 -in one ratifying nation is sufficient to secure protection in the others. ${ }^{101}$ But signatory nations may make

91. 1 id. at $368-71$.

92. BerLIN Revision of 1908 art. 8. The first step toward increasing the author's translation rights was taken in the Additional Act of 1896 . Under that agreement, a national of a member state could translate without restriction only if, after ten years, the author had not published a translation in the national language of the translator's country. Additional Act of 1896 art. 3 in 2 Ladas 1135-6.

93. BRussels Revision of 1948 arts. 11-14. The author's rights in regard to these uses of his work were first mentioned in the 1928 Revision. ROME REvision of 1928 arts. 11-13.

94. Id. at art. 6 bis (1).

95. The literature on moral rights is extensive. The leading work on the subject is Roeder, The Doctrine of Moral Right, 53 Hanv. L. Rev. 554 (1940). See also Katz, The Doctrine of Moral Right and American Copyright Law in Ascap, Fourtu Corrugut Law Symposium 79 (1952); 1 Ladas 575-604.

96. See note 94 supra.

97. 1 LAdAS 579.

98. See $1 \mathrm{id}$. at 575-81. An author's moral rights may also allow him to object to mutilation in other types of adaptation, such as dramatization or translation. Roeder, The D'octrine of Moral Right, 53 HARv. L. Rev. 554, 577 (1940). See p. 1081 infra.

99. Berne Convention of 1886 art. II $\S 2$.

100. This definition appears in the Brussels Revision of 1948 art. 4(4). For a critical discussion of the publication requirement as defined in the Convention, sce 1 LADAS 288-310. The 1948 Brussels Revision states: “. . . '[P]ublished works' shall be understood to be works copies of which have been issued and made available in sufficicnt quantities to the public." Brussers Revision of 1948 art. 4(4) (the italicizcd portion was added in 1948).

101. Brusseis Revision of 1948 arts. 4(1), (2). Although there is some doubt, it appears that failure to fulfill formalities, such as deposit of copies with the court, 
compliance by their own nationals with domestic formalities a condition precedent to copyright protection at home. ${ }^{102}$

\section{Duration of Copyright}

Berne sets a uniform term of protection for most works-the author's life and fifty years after his death. ${ }^{103}$ Initially, the duration of copyright in most works equalled the term provided by the domestic law of either the publishing country or the protecting country, whichever period was shorter. ${ }^{104}$ This "comparison of terms" rule persisted through all revisions of the Berne Convention except the 1948 Brussels Revision, ${ }^{105}$ which adopted the uniform lifeplus term. ${ }^{106}$

\section{Reservations}

However unifying Berne may appear to be, nations which were already members when a revision was enacted were permitted to reject all or part of the revision and remain bound pro tanto by the earlier version.107 Japan, for instance, still adheres to the 1886 ten-year translation provision, ${ }^{109}$ even though she has accepted other portions of the 1928 Rome Revision. ${ }^{100}$ And Great Britain has refused to give retroactive application to any of the articles. ${ }^{110}$

cannot prevent a foreigner from seeking judicial relief for infringement. See 1 LADAS 273-5; 2 Unesco Copyriget Bull. 94-103 (No. 2-3 1949).

For an instance in which the courts of a member nation have denied protection by construing "publication" narrowly, see pp. 1079-80 infro.

102. Brussels Revision of 1945 art 4(2). All texts of the Convention apply only to copyright acquisition outside the country of origin. But the liberalization of copyright in the Union did prompt action to secure automatic copyright for nationals in their home countries. 1 LADAS $187-9$.

103. BRUSSELS REviston of 1948 art. 7(1). Article 7(2) grants the foreign author the right to claim the longer period which a nation extends to its native authors. But only seven countries grant terms greater than fifty years post mortem astctoris: Brazil (60), Colombia ( 80 ), Cuba ( 80 ), Spain ( 80$)$, Guatemala (perpetual), Nicaragua (perpetual), and Portugal (perpetual). 2 UNesco Copyrigrt BurL 70-81 (No. 2-3 1949).

104. Berne Convention of 1886 art. II, $\$ 2$.

105. BerLin Revision of 1908 art. 7; Rosie Revision of 1923 art. 7.

106. See note 103 supra. The comparison of terms rule still applies to cinematographic and photographic works. Brussels Revision of 1948 art. 7(3).

107. See, e.g., RoMre Rerision of 1923 arts. 25(3), 23.

108. 1 Ladas $92-3,99,141-4,386-8$.

109. 1 id. at 121 .

110. 1 id. at 352-3. Of the members of the Berne Union, supra note 73, only twenty-two have ratified without reservations. Drort D'AUTEur 2 (Jan. 15, 1953). Seven countries have reservations to article 18 on retroactivity: Australia, Great Britain, India, New Zealand, Norway, Thailand, and Union of South Africa. Id. at 3. And nine nations remain bound by the original ten-year translation provision: Greece, Iceland, Irish Free State, Italy, Japan, Netherlands, Thailand, Turkey, and Yugoslavia. Ibid. For 3 complete list of reservations presently in force, see id. at $2-3$. 
Berne, however, requires a nation first signing the Convention after a revision to accept the then current text in its entirety. ${ }^{111}$

As the net result of periodic modification, Berne now relies only mengerly on domestic legislation to determine what kind of protection member nations must grant to works emanating from another signatory. The current version ${ }^{112}$ protects any type of work published within the Union and extends its protection over a period which does not vary from country to country. Foreign authors need observe neither the formalities imposed by the protecting nations, nor those of the country of origin. Translations receive the same protection as originals. And although radio use of protected works may be regulated by domestic law, ${ }^{113}$ the moral rights clause prevents any substantial diminution of the author's control. Nations remain free to legislate only on subsidiary issues such as newspapers' use of oral works, ${ }^{114}$ retaliatory action, ${ }^{116}$ seizure of pirated works, ${ }^{116}$ and use of quotations. ${ }^{117}$

\section{Berne Protection of United States Works}

Despite the fact that United States copyright is practically unavailable to many foreign authors, ${ }^{118}$ American authors find it easy to obtain protection in Berne countries. The Convention protects any work published in a member

111. Rome Revision of 1928 art. 28(3). Countries not already members of the Union were in fact given a three-year period after the 1928 conference in which they could ratify either the 1908 or the 1928 treaty. Ibid. But many nations were slow to ratify the 1928 revision. 1 LADAS 121-2. Similar provisions applied to ratification of other revisions. BerLin ReVISION of 1908 art. 25; BRussels REvision of 1948 arts. 25, $27(2)$.

112. The following sixteen nations have ratified the Brussels Revision of 1948: Belgium, Brazil, France and Algeria, Israel, Liechtenstein, Luxembourg, Monaco, Morocco (French Zone), Philippines, Portugal, Spain, Tunisia, Turkey, Union of South Africa, Vatican City, and Yugoslavia. Drolt d'Aureur 4 (Jan. 15, 1953) (translated from the French by Judith Caro). Thailand and South West Africa are the only Berne members still bound wholly by the Berlin Revision of 1908. All others listed note 73 supra, have adopted the Rome Revision of 1928. Great Britain will probably ratify the Brussels Revision shortly. 103 L.J. 5 (1953).

For a detailed summary of the changes effected by the 1948 Revision, sec The Revisious of the Berne Convention at Brussels, 1 Unesco Copyright Bull. 10 (No. 2 1948).

113. Brussels Revision of 1948 art. 11 bis (2).

114. Id. art. 2 bis (2). See Williams, Nezespaper Copyright and the Intcrnational Copyright Union, 8 Tulane L. Rev. 98 (1933).

115. BRUSSELS REvision of 1948 art. 6.

116. Id. art. 16.

117. Id. art. 10. For a complete tally of the matters on which nations may legislate, see The Revision of the Berne Convention in Brissels, 1 Unesco Copyrigut Buld. 10, 14 (No. 2 1948).

118. See pp. 1067-70 supra. 
nation. ${ }^{119}$ The treaty provides that "publication" consists only of issuing copies to the public ${ }^{120}$ or, if the work is first published in a non-member, putting copies on sale in a member nation. ${ }^{121}$ Thus, an American can meet the technical requirements for protection in the Berne Union simply by shipping a few copies to a Canadian bookseller at the same time the work goes on sale here. ${ }^{128}$

\section{Retaliation}

Despite a 1914 provision permitting Berne members to restrict the protection given to nationals of non-Berne countries failing to protect Berne works "in a sufficient manner,"123 retaliation sufficient to force a change in American copyright policy has not materialized. Throughout the 1930's, at least, the United States seemed on the verge of approving the treaty, ${ }^{12 t}$ which had the support of Presidents Hoover ${ }^{125}$ and Roosevelt. ${ }^{125}$ Europeans probably considered large-scale retaliation unnecessary or inopportune. ${ }^{12 \pi}$

119. See text at note 101 supra.

120. BerLin Revision of 1908 art. 4, $\$ 4$; also see Rose Revision of 1923 art. 4(4).

121. BERLIN REVISION OF 1908 art. 6.

122. Canada is a Berne member. See note 73 supra.

123. "When a country not belonging to the Union does not protect in a sufficient manner the works of authors within the jurisdiction of a country of the Lnion, [the Berlin Revision] can not prejudice, in any way, the right which belongs to the contracting countries to restrict the protection of works by authors who are, at the time of the first publication of such works, subjects or citizens of the said country not being a member of the Union, and are not actually domiciled in one of the countries of the Union." Admitional Protocol to the International Copraight Conienition: os BerIIN art. 1 (signed at Berne, 1914). The substance of this provision was carried into the Rome Revision of 1928 art. 6(2)-(4). In the 1948 revision, a strengthening provision was added: "If the country of first publication avails itself of this right [to retaliate], the other countries of the Union shall not be required to grant to works thus subjected to special treatment a wider protection than that granted to them in the country of first publication." Brussezs Revision of 1948 art. 6(2).

124. See text at note 136 infra. The Senate actually ratificd the treaty in 1935 , without a recorded vote, but because of an agreement in the Senate the ratification was reconsidered. See Rep. Register of Copyrights 12-13 (1935); id. at 13 (1936).

125. See Statement of Wallace McClure, Treaty Division, Dep't of State, in Hearings before Senate Committee on Patents on H.R. 12549, 71st Cong., 3d Sess. 196 (1931).

126. See Letter of President Franklin D. Roosevelt to Robert Underwood Jolnnson, in Hearings before Committee on Forcign Relations on S. 1928, Pt. 2, 73d Cong., 2d Sess. 57-8 (1934); Hearings before Scnate Committee on Forcign Relalions on Exculize E, 73d Congress, 75th Cong., 1st Sess. 45 (1937).

127. Solberg, The Present International. Copyrugat Situatiun 16-17 (1934). The British did not retaliate because, although they bore the brunt of the discrimination fostered by the manufacturing clause, they exported more to the United States than they imported from the United States. Hearings, stipa note 6, at 221-2. Also see Jislice in Copyright Needed, 126 Publsshers WeEkLy 912 (1934); Ostertag, Refort of the Principal Events in the Domain of Copyright from 1931 to 1937, Drort I'AuTeur (July, 1937) (translated from the French by Gertrude Rosenstein). 
Only The Netherlands has attempted serious retaliation; that country, in the 1930's, refused copyright to many American works. ${ }^{128}$ Dutch piracy was sanctioned not through recourse to the Berne clause legalizing retaliation, but by the Dutch courts' narrow interpretation of "publication."120 In 1936, the highest court of The Netherlands upheld unauthorized use in Holland of a story which had first appeared in Colliers' magazine. ${ }^{130}$ Although copies of Colliers' had been distributed in Canada to meet the Berne requirements, the court held that this was not sufficient publication within the meaning of the Convention. ${ }^{131}$ A few years later, however, the court retreated part way by refusing to condone piracy of "Gone With The Wind."182 The book had been sent in unbound sheets to Canada, where it had been bound and distributed. The Dutch high court held that binding the books in Canada fulfilled the Berne requirements. ${ }^{133}$ Since American publishers customarily have some copies bound in Canada, no effective retaliation now exists in The Netherlands. ${ }^{134}$

\section{American Attempts to Join Berne}

Fear of retaliation did provoke numerous attempts by American publishers and authors and by the State Department to bring the United States into the Berne Union. ${ }^{135}$ Between 1930 and 1941, at least seven separate bills designed to effectuate United States entry into the Berne Union were introduced in Congress. ${ }^{136}$ But the threat of piracy did not sway the printers

128. See Hearings before Senate Committee on Forcign Relations on Exccutivc E, 73d Congress, 77th Cong., 1st Sess. 18-19, 21, 24, 28-9, 64-5, 77-81 (1941).

Canada also reacted during the 1920 's, imposing the equivalent of a manufacturing; clause on American publishers. This action was taken under the permissive Berne clatuse of 1914. See note 123 supra. But it was never implemented by ministerial action. 2 LADAs 907-9; Droit D'Auteur (Sept. 15, 1923) (translation from the French in 1 CaN. B. Rev. 780 (1923)).

129. For the Berne definition of "publication," which the Dutch courts construed, see pp. 1078-9 supra.

130. Sax Rohmer (Pseudonym for A. H. Sarsfield Ward) v. Uitgeversmantschappij "De Combinatie," Supreme Court of The Netherlands (1936), Droir D'AutEun (July, 1937) (translated from the French by Gertrude Rosenstein). For a discussion of this case see Saher, American-Netherlands Copyright Problenus, 1 WorLd Trude L.J. 371, 379-80 (1946).

131. See Saher, supra note 130 , at $379-80$.

132. See id. at 380-2.

133. See Hearings, supra note 6 , at 48. For a discussion of the general problem of American-Netherlands relations and an account of the long legal history of the "Gono With The Wind" case, see Saher, supra note 130, at 380-2. The case was finally settled in 1945. Ibid.

134. Hearings, supra note 6 , at 37 . But see $i d$. at 213 , indicating that there may still be scattered instances of retaliation by the Dutch.

135. See authorities cited note 136 infra, passim.

136. 1) Hearings before Committee on Patents on H.R. 6990, 71st Cong., 2d Sess. (1930) ; 2) Hearings before Senate Committee on Patents on H.R. 12549, 71st Cong., 3d Sess. (1931); 3) Hearings before Committee on Patents on H.R. 10976, 72d Cong., 
or the motion picture and radio industries from their stand against membership. ${ }^{137}$ United States adherence to Berne would have necessitated modifying the manufacturing clause to give protection to works printed abroad. ${ }^{135}$ Printers and book manufacturers argued that since printing costs abroad were cheap, foreign authors might desert American printers. ${ }^{139}$ In addition, they said, American publishers might print abroad and ship finished copies back: to the United States. ${ }^{140}$ The movie and radio industries feared that Berne's emphasis on authors' rights would make adaptation of literary works more expensive and less secure. ${ }^{141}$ And in their view, Berne's grant to authors of moral rights would straitjacket attempts to alter scripts.142 These policy justifications were buttressed by the claim that granting copyright in "oral" works, such as speeches, was unconstitutional, since Article I of the Constitution limits congressional power to protection of "Writings." "143

1st Sess. (1932) ; 4) Hearings before Committee on Forcinn Relations on S. 192\$, 73d Cong., 2d Sess. (1934) ; 5) Hearings before House Committe on Patcuts on Recisions of the Copyright Lawes, 74th Cong., 2d Sess. (1936); 6) Hearings before Scratc Committee on Forcign Relations on Executize E, 73d Congress, 75th Cong., 1st Sess. (1937); 7) Hearings before Senate Committec on Forcign Relations on Excention E, T3d Congress, 77th Cong., 1st Sess. (19:1). For a summary of this history see Note, Rcrision of Copyright Law, 51 HANv. L. REv. 906 (1938). And for background of this legislation, see Solberg, The Present Copyright Situation, 40 Yale L.J. 184 (1930).

137. See notes $1+0-43$ infra.

138. The Rome Revision, in force when this legislation was proposed, state unequivocally that no formalities may be required. Rosre Revision of 1928 art. 4, $\$ 2$.

139. See authorities cited note 140 infra.

140. Hearings, sutpra note $12 S$, at 21-2, 116-2S, 156-\$2; Hcarings before Commitice on Foreign Relations on S. 1928, 73d Cong., 2d Sess. 10-18, 21, 27, 89-91 (1934). Periodical publishers also opposed the treaty. Hcarings, supra note 128, at 115-17, 18993; Hearings before Senate Committec on Forcign Relations on Executioe E, T3d Congress, 75th Cong., 1st Sess. 31-, 36-9 (1937); Hearings before Commiltec on Forciyns Relations an S. 1928, 73d Cong., 2d Sess. 85-8 (1934).

141. See Hearings, supra note 128 , at S9-105, 128-35, 141-56; Hcarings before Conmittee on Foreign Relations on S. 1928, 73d Cong., 2d Sess. 6S-85 (1934); Hearings before House Committec on Patchts on Revision of the Copyright Lans, 74th Cong., 2d Sess. 1005-44 (1936) ; Hearings before Senatc Committec on Foreigu Relations on Excerstive E, 73d Congress, 75th Cong., 1st Sess. 2-30, 47-50 (1937). On the international copyright problems of the broadcasting industry see Brown, Intersational Broadeastivg: Its Copyright Aspect, 15 So. CaLIF. L. REv. 164 (1942); Diamond \& Adler, Proposed Copyright Revision and Phonograph Records, 11 AIR L. Rev. 29 (1940); Duffy, Isternational Copyright, S AIR L. Rev. 213 (1937); Hepp, Radio Broadeastirg astd the UNESCO Survey of World Copyright Law, 10 Fen. Cosss. B.J. 67 (1949); Homburg, Radio Broadcasting and the Instcrsational Protcction of Intellectual Rights, 10 FED. Cosas. B.J. 59 (1949); Simpson, The Copyright Situations as Affecting Radio Broadcasting, 9 N.Y.U.L.Q. REv. 180 (1931) ; Straschnov, The Mostaco Ordinantec on Copyright with Respect to Radio-Broddcasting, 10 Fen. Conns. B.J. 189 (1949); Note, Adhercitec to the Interinational Copyright Union and Proposed Copyright Reform, 12 AIR L. Rar. 49 (1941) ; Note, 1 J. Radro L. 390 (1931).

142. See authorities cited note 141 supra.

143. "The Congress shall have Power ... To promote the Progress of Science and useful Arts, by securing for limited Times to Authors . . . the exclusive Right to their respective Writings. . . " U.S. Const. ARr. I, \& 8 (emphasis added). 
Other arguments advanced against ratification served largely as makeweights, but nevertheless may have been effective. Some claimed that ratifying before United States laws were amended to conform to the Convention would cause confusion by superimposing Berne on conflicting domestic law. ${ }^{144}$ But this contention could hardly have represented a real motive for opposition. Congress could have amended domestic law before adopting the treaty or taken both steps at the same time. ${ }^{145}$ Other objections were that the treaty had originated in Europe and was un-American ${ }^{146}$ and also that Nazi Germany would be a fellow member. ${ }^{147}$

Poor strategy aborted Berne's adoption. In response to the charge that confusion would result unless domestic law were changed first, ${ }^{448}$ American proponents of Berne incorporated treaty ratification in a general revision of the copyright code. ${ }^{149}$ Quite apart from the provisions aimed at reconciling United States law with Berne, the revision included many controversial changes ${ }^{150}$ which caused groups which had previously championed Berne to oppose any revision at all. Thus, the American Society of Composers, Authors and Publishers (ASCAP), faced with threatened repeal of Section $101(b)^{151}$ guaranteeing minimum damages for infringement of musical copyrights, turned its full weight against both amendment and ratification. ${ }^{150}$ As a result of such concerted opposition, Congress failed to ratify Berne.

144. Hearitigs before Committee on Foreign Relations on S. 1928, 73d Cong., 2d Sess. 63-4, 77, 88 (1934); Hearings before Committee on Patchts on H.R. 6990, 71st Cong., 2d Sess. 222 (1930); Hearings before House Committee on Patcnts on Revision of the Copyright Laws, 74th Cong., 2d Sess. 1012-13 (1936); Hearings, supra nate 128, at 89-90. Also see Note, Revision of Copyright Lazv, 51 HARv. L. Rev. 906, 908-9 (1938).

145. Simultaneous amendment and ratification were finally undertaken, but combination of the two seemed improvident. See text at notes 148-52 infra.

146. Hearings before Senate Committee on Forcign Relations on Executive E, 73d Congress, 75th Cong., 1st Sess. 32 (1937).

147. Even book publishers, Hearings, supra note 128, at 106-8, and authors, Hearings before House Committee on Patents on Revision of the Copyright Lanes, 74th Cong., 2d Sess. 238, 242, 514-15, 548-50 (1936), succumbed to this argument against the treaty, although they had previously been ardent supporters of Berne. See authorities cited notc 135 sipra.

148. See text at note 144 supra.

149. See Hearings before House Committee on Patents on Revision of the Copyright Lawes, 74th Cong., 2d Sess. (1936).

150. For discussion of these changes see Pforzheimer, Copyright Reform and the Duffy Bill, 47 Yale L.J. 433 (1938).

151. 17 U.S.C. $\S 101$ (b) (Supp. 1952).

152. See Burkan, Proposed Amendment of the Copyright Law 5 (1935); Pforzheimer, Copyright Reform and the Duffy Bill, 47 YALE L.J. 433, 436 (1938); statement of Sydney M. Kaye, attorney for the National Association of Broadcasters in Hearings, supra note 149, at 399: "The opposition to the Berne Convention on the part of A.S.C.A.P. is another smokescreen, . . their real ground for opposition to this bill remains the elimination of the onerous minimum-penalty clause." See also Appleman, Compromise in Copyright, 19 B.U.L. REv. 619 (1939); Duffy, International Copyright, 8 AIR L. REv. 213, $221-2$ (1937). 


\section{The Unesco Universal Copyright Convention}

\section{The Post-War Problem}

Dissatisfaction with international protection as it existed at the end of World War II was twofold. Europe wanted the United States brought into some organization for copyright control. ${ }^{103}$ The alternatives-return to mutual piracy or mere perpetuation of America's one-way excursion into Berne via Canadian publication-would ruin Europe's chances of benefiting from the lucrative post-war market in America. ${ }^{164}$ Conversely, the overseas demand for American literary and artistic products had soared. Because the motion picture, publishing, and music industries had found expanded marliets abroad, the United States had become the world's leading net exporter of copyrightable materials. ${ }^{155}$ American interests now feared loss of this European market which, despite instances of retaliation in the 1930's, they had previously thought secure. ${ }^{150}$

The problem was how to set up an organization which the United States would join and which would at the same time achieve fair conyright protection. The consensus was that any new arrangement would have to develop outside of the existing treaty structure. ${ }^{157}$ Increasing the membership of Berne was considered impossible, since almost all the American nations had failed to approve that Convention. ${ }^{10 s}$ And if Berne standards had to be lowered to attract more nations, its members would have protested strongly.153

UNESCo's study began in $19477^{100}$ and the finished product, the U'niversal Copyright Convention (UCC), was completed in 1952. ${ }^{101}$ The Usvesco Con-

153. See Ostertag, supra note 127; Saher, supra note 130 , at $3 \$ 3$.

154. Hearings, supra note 6 , at 217-23.

155. Id. at 3, 217-23.

156. Id. at $63,153$.

157. Recommendations of the Committe of Experts, 3 U:resco Corynuar BuL. 9 (No. $3+1950$ ). And see $i d$. at 38-43.

158. See list of members, note 73 supra.

159. For indications of the reluctance of many continental countries to tolerate diminished protection abroad, and their insistence on safeguarding the Berne Union standards among themselves, see text at notes 213-17 infra.

160. 1 Unesco Copyrater Bull. 2 (No. 1 1948); Divon \& Goldblatt, Toacard a Unzacrsal Copyright Contention, 24 Dep'T STate BuLn. $2 \mathrm{SS}$ (1951); Kuhn, The Worla of Unesco on Copyright, 43 Axr. J. Ixт'L L. 343 (1949); note 15 supra.

161. The Intergovernmental Copyright Conference took place in Geneva, Switzeriand and culminated on September 6,1952 in the adoption and signing of the Univer:al Conyright Convention. For a complete text of the Convention and the Kepart wi the Rapporteur-General, see 5 Unesco Copyrigit But. 30 (No. 3-4 1952).

Fifty nations participated in the Geneva Conference, but only furty mations signed the Convention: Andorra, Argentina, Australia, Austria, Belgium, Brazil, Canada, Chile, Cuba, Denmark, Finland, France, Gurman Fuderal Republic, Guatemala, Haiti, Honduras, India, Ireland, Israel, Italy, Japan, Liberia, Lusembisurg, Mlesico, Monaco, Nicaragua, Netherlands, Norway, Peru, Portugal, Salvador, San Marino, Spain, Sweden, Switzerland, Great Britain and Northern Ireland, United States, 
vention differs markedly from the Berne plan. While Berne developed an international code assuring uniformly high standards of protection, UCC relies heavily on the domestic law of the protecting country and hence provides variably lower standards. ${ }^{162}$ To make UCC more palatable to the United States and other balky nations, UNESCo designed the Convention to require only minimal changes in domestic law. ${ }^{163}$

\section{Scope of Protection}

Works protected. UCC obligates each member to protect "literary, scientific, and artistic works, including writings, musical, dramatic and cinematographic works, and paintings, engravings, and sculpture."104 A nation may adhere to the Convention even though it protects some art forms, such as applied art, under legislation other than copyright statutes. ${ }^{105}$ And it country can ratify UCC although its domestic law prohibits it from protecting certain material-architecture, for example. ${ }^{166}$ If, however, a nation refuses to protect a class of works, it defaults the right of its nationals to copyright similar works in other members. ${ }^{167}$ UCC does not protect oral works. ${ }^{108}$

The Convention has no retroactive effect. ${ }^{169}$ Berne provided that a work protected in the country of its origin at the time of ratification would thereafter be protected in other signatory nations, whether or not these nations had previously protected the work. ${ }^{\mathbf{1 7 0}}$ But certain American interests might have

Uruguay, Vatican City, Yugoslavia. The ten nations which participated but did not sign are: Colombia, Dominican Republic, Egypt, Greece, Indonesia, Iran, Thailand, Turkey, Venczuela, and Viet Nam. See Unesco General Conference, Seventir Session, Report of til: Results of the INTER-Governimental Conference on Copyright, 7C/PRG/8, (Oct. 10, 1952) (translated from the French); Communication to the YALE LAw JourNAL from Dr. Arpad Bogsch, Copyright Division, Unesco, dated March 31, 1953, in Yale Law Library. Andorra is the only country which has officially ratified the Convention thus far, although other nations are actively considering ratification. Communication, supra. On the Convention generally, see Honig, International Copyright Protection and the Draft Universal Copyright Convention of Unesco, 2 INT'L \& CoMp. L.Q. 88 (1953); Honig. Universal Copyright Convention, 1 INT'L \& CoMP. L.Q. 217 (1952); Schulman, A Reala istic Treaty, AM. Writer (Nov. 1952).

162. Outside of European nations, protection afforded by domestic law is not so complete as that assured by the Berne Convention. See Works Protccted and Economic Rights, 2 Unesco Copyrigat Buld. 18 (No. 2-3 1949).

163. See Escarra, Comment on International Copyright Protection, 2 UNesco CoryRIGHT BULL. 2 (No. 4 1949).

164. UCC art. I.

165. UCC art. IV, § 4. And see Report of the Rapporteur-General, 5 UNesco CopyRIGET BULL. 42, 51-2 (No. 3-4 1952).

166. Ibid. For example, the United States could adhere, even though the Constitution were construed to prohibit protection of "oral" works. See note 143 suspra.

167. Report of the Rapporteur-General, supra note 165, at 52.

168. See text at notes 164 supra and 189-93 infra.

169. UCC art. VII.

170. See p. 1075 supra. 
suffered from such a provision. It might, for example, force an American movie producer to start paying royalties to a foreign author whose novel the producer had adapted when it was not protected in the United States. ${ }^{171}$ In deference to the American position, the Conference considered a compromise based on the Inter-American Agreement of 1946.172 Under a stipulation lilie this, previously unprotected works become protected; but a person who has reproduced such a work before ratification can continue to do so without the author's consent. ${ }^{173}$ The United States delegation to the UNesco Conference, however, blocked the compromise by maintaining that any provision for retroactive protection would make ratification by the United States virtually impossible. ${ }^{174}$

Substantive rights protected. For the most part, UCC leaves each member state free to decide what particular rights will be safeguarded and under what conditions of license, fair use, and assignment those rights may be exercised. ${ }^{175}$ Some nations wished to guarantee moral rights, in addition to performance and reproduction rights. ${ }^{170}$ But the Conference rejected these proposals because specific guarantees might be read to limit UCC's application and because they might conflict with local law. ${ }^{177}$

Translation rights. Although UCC flatly states that "Copyright shall inclurle the exclusive right of the author to . . . authorize the making and publication of translations," 178 the Convention actually curtails this right. ${ }^{170}$ During the seven years following the first publication of his work, he has absolute control over its translation. At the end of seven years, however, the author may lose his right to prevent unauthorized translation. If at that time no authorized translation has appeared in the national language of a member state or such translations are out of print, a national of that state may acquire a nonexclusive, non-transferable right to translate the work into his national language.

The would-be translator must show that he has contacted the copyright proprietor and has been denied permission. If he has been unable to find the

171. See Hearings before Committee on Forcign Relations on $S .192 S, 73 \mathrm{~d}$ Cong., $2 \mathrm{~d}$ Sess. 54, S0-2 (1934) ; Hearings, supra note 128, at 20-21, 32, 75, 111, 128-35.

172. Inter-ANIERICAN CONVENTION of 1946 art. XVII(2).

173. Ibid. And see Report of United States Delegate to Inter-Ariesuca:: Co:iFerence of Experts on COPyriget, U.S. Cont. Ser No. 99, 28-9 (Def't of State 1947).

174. Report of Rapporteur-General, supra note 165 , at 55-6.

175. The Convention requires only that "[e]ach Contracting State [undertalie] to provide for the adequate and effective protection of the rights of authors and uther copyright proprietors...." UCC art. I.

176. Repart of the Rapporteur-General, supra note 165 , at $46-7$.

177. Ibid.

178. UCC art. V, $\$ 1$.

179. UCC art. V, § 2. See Evans, Role of Translation in the Alticremen of Pcace, Lir. Cong. Info. BulI, App. (Dec. 22, 1952). 
proprietor, the translator must contact the publisher, or, failing that, the consular representative of the author's nation. A member state electing to take advantage of the translation provision of UCC must assure the athor reasonable compensation. It must also provide a means for transmitting the money to the author, "assure a correct translation of the work," and giarantee that the original title and the author's name will appear on all copies. ${ }^{180}$

How long an author should be empowered to prevent unauthorized translation was debated extensively at the Unesco Conference. Most of the delegations which fought to shorten the period represented less developed nations, in which making works of foreign authors readily available in the national language is essential to cultural growth.181 Many of these nations, though members of Berne, had not adopted Berne provisions giving long-lasting translation rights to authors. ${ }^{182}$ Another group, preponderantly Middle Eastern, had rejected Berne entirely. ${ }^{183}$ The Conference hoped to attract all of these nations by making translation easier and less expensive. On the other hand, it sought to pacify the continental countries, most of which opposed a short term as too likely to hurt an author's position in foreign nations. ${ }^{184}$ The translation article strikes a reasonable balance between the two conflicting interests. It makes literature available in another language after a short period, and yet guarantees the author some economic benefit even after the seven-year term.

\section{Formalities}

Published Works. Any author publishing in a member nation, or a national of a member state no matter where he publishes, can easily acquire protection in all other members. ${ }^{185}$ In a nation which grants copyright to its own nationals without formalities, mere publication suffices to protect the foreign author. ${ }^{186}$ To protect the author in countries which, like the United States, require their own nationals to fulfill formalities, every published copy must contain notice of copyright-the symbol @e, the name of the copyright owner,

180. Ibid.

181. E.g., Greece, India, Japan, Mexico, and Turkey led the fight for a short protected period before translation. Report of the Rapportcur-General, supra note 165, at 53-5. For the debates on article $V$ at the Conference, see UnEsco, MINUTEs of Tul: Intergonernmental Copyright Conference, CoMmittee on Right to Tuanslate, DA/WG/SR/7-10, passin (1952).

182. 1 LADAS 386-8.

183. See notes 5 and 73 supra.

184. Unesco, Minutes of the Intergovernmental Copyrigit Conference, ConMitTeE on Rights to Translate, DA/WG/SR/7-10, passin (1952).

185. UCC art. II, § 1 : "Published works of nationals of any Contracting State and works first published in that State shall enjoy in each other Contracting State the same protection as that other State accords to works of its nationals first published in its own territory."

186. Ibid. 
and the year in which the work was first published. ${ }^{187}$ Signatory nations can impose no other conditions precedent to protection. ${ }^{189}$

"Publication" means merely "the reproduction in tangible form and the general distribution to the public of copies of a work from which it can be read or otherwise visually perceived."189 Under United States pressure, ${ }^{100}$ the Conference rejected the Berne rule that solely audible performance ur reproduction of a work constitutes "publication."191 The American delegation claimed that inconvenience and confusion would result if a broadened definition were adopted. ${ }^{192}$ Furthermore, a definition of "publication" which would protect phonograph records would necessitate a change in United States domestic copyright law, a prospect which would probably alienate American composers' groups otherwise disposed to support the treaty. ${ }^{103}$

Although UCC obligates all its members to protect a work published in one member state, residents of country $A$ who publish in country $B$ and

187. UCC art. III, § 1. And see Report of the Rapporteur-General, supra note 165, at $49-51$.

18S. "[A foreign work shall be protected in a country imposing formalities] if from the time of the first publication all the copies of the work published with the authority of the author or other copyright proprietor bear the symbol (c) accompanied by the name of the copyright proprietor and the year of first publication placed in such manner and location as to give reasonable notice of claim of copyright." UCC art. III, § 1.

A member nation may continue to impose additional formalities on its oun nationals. UCC art. III, \$2. It may also require appearance through domestic counsel and deposit of copies with the court as conditions precedent to seeking judicial relief. But failure to comply with these conditions does not affect the validity of the Copyright. Id. \& 3 .

189. UCC art. VI (emphasis added).

190. See Report of Rapporteur-General, supra note 165, at 55; Arrenucux Bar Asso-

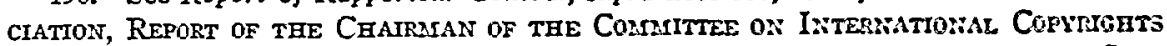
16-22 (1953) ; Anterican Bar Association, Report of the Chamasa: of tue Stc-

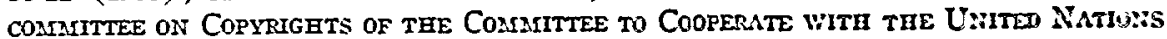
and Unesco, Respecting the Geneva Universal Copyrigat Conientio: 11 (1952).

191. See Report of Rapporteur-Gencral, supra note 165, at 55.

192. See authorities cited note 190 supra.

193. A recording is not in itself a copy of the work recorded within the meaning of 17 U.S.C. $\$ 1$ (Supp. 1952). Corcoran v. Montgomery Ward Co., 121 F.2d 572 (9th Cir. 1941) (phonograph records); White-Smith Míusic Pub. Co. v. Apollo Co.n 209 U.S. 1 (1907) (player piano rolls). And mere broadcast or performance of a recording or seript is not a publication. Ferris v. Frohman, 223 U.S. 424 (1912) (theatrical performanee); Uproar Co. v. National Eroadcasting Co., S F. Supp. 358 (D. Mass. 1934), modificd, 81 F.2d 373 (1st Cir.), cert. denjed, 298 U.S. 670 (1936) (broadeast); Nult v. National Institute, Inc., 31 F.2d 236 (1st Cir. 1929) (lecture).

The general doctrine has, however, been surrounded by limitations. Thus, the salc of a phonograph record may be a publication. Shapiro, Bernstein \& Co. v. Alirasle Record Co., 91 F. Supp. 473 (N.D. Ill. 1950). Contra: Yacubian v. Carroll, 74 U.S.P.Q. 257 (Calif. Dist. Ct. 1947). And using the musical laugh of "Woody Woodpedser" in broadcasts and motion picture cartouns constitutes "maling [the laugh] publie" under the California Civil Code. Blanc v. Lantz, \&3 U.S.P.Q. 137 (Calif. Surer. Ct. 1949). For a discussion of the peculiar problems of phonograph records and the publication issus, see Dubin, Copyright Aspects of Sound Recordings, 26 So. CALIF. L. Rev. 139 (1953); 
then seek protection in $A$ must still comply with $A$ 's formalities. ${ }^{104}$ A concession to the United States, this provision guarantees that the Convention will not excuse American residents who publish abroad from complying with the United States manufacturing clause. ${ }^{105}$

Unpublished works. UCC protects any unpublished work produced by a national of a member state, without requiring the author to fulfill any formalities. ${ }^{190}$ Copyright issues even though the author both resided and created the work in a non-member nation. ${ }^{197}$

\section{Duration of Copyright}

In basing the duration of copyright on domestic law, UCC enacts the "comparison of terms" rule which Berne recently discarded. ${ }^{108}$ Under the UNEsco plan, the term during which a published work receives protection is either that prescribed by the protecting nation or the one enacted by the nation in which the work was first published, whichever term is shorter. ${ }^{100}$ For unpublished works, the period is similarly determined by comparing the law of the protecting nation with that of the member nation of which the author is a national; again the shorter term prevails. ${ }^{200}$

UCC, however, assures a minimum period of protection. If the domestic law of a member state bases duration on the date of publication, that nation must protect the foreign author for at least 25 years thereafter. ${ }^{201} \mathrm{~A}$ country which measures duration by the author's life must extend protection for a minimum of 25 years after the foreign author's death. ${ }^{202}$ Since the domestic

MacDonald, The Lawe of Broadcasting in Federal Bar Ass'n, 7 Copyriant Pronlems ANALYZED 31, 44-6 (1952).

On the attitude of American groups toward incorporating the Berne rule in UCC, see American Bar Ass'n, Report of the Chairman of the Committee on International Copyrights 16-22 (1953); AMerican Bar Ass'n, Report of the Cuatrusan of the Subcommittee on Copyrights of the Committee to Cooperate witu the United Nations and Unesco, respecting the Geneva Universal Copybight ConvENTION 11-12 (1952). Also see HowerL 61-7.

194. UCC art. II, \& 3.

195. See Hearings, supra note 6, at 69-82.

196. UCC art. II \& 2 ; $i d$. art. III, § 4.

197. This construction seems to follow from UCC art. II, § 2: "Unpublished works of nationals of each Contracting State shall enjoy in each other Contracting State the same protection as that other State accords to unpublished works of its own nationals."

198. See p. 1077 sipra.

199. For published works, the state in which protection is sought nced not give protection for a longer period than that of the state of publication. UCC art. IV, § 4. And the protecting nation may give a shorter term of protection if its domestic law so provides. See id. art. II, $\S 1$; Report of the Rapporteur-General, supra note 165, at 51-2.

200. The method of computing is the same as for published works, note 199 supra, but the term of the country of which the author is a national is used, instead of the country of first publication. UCC art. II, § 2.

201. UCC art. IV, \&2.

202. Ibid. 
law of every principal nation currently provides a term longer than the minimum which the Convention guarantees, ${ }^{203}$ simple comparison of terms will usually decide how long protection lasts.

For the purposes of comparing terms, a nation which makes copyright renewable for consecutive periods is deemed to grant protection for the aggregate of the terms. ${ }^{204}$ But a member state need not protect a work for longer than the first term if the author does not comply with renewal requirements. 05 For instance, United States law confers copyright for 28 years, renewalble for one identical period. ${ }^{201}$ Hence, UCC considers the American term to lse 56 years. But an author whom UCC protects by applying United States law must renew after 28 years. ${ }^{207}$

The United States delegation argued that the period should depend solely on the domestic law of the protecting nation, since comparing terms would he unduly complex.20s The Conference rejected this proposal on the ground that - European experience with the comparison of terms rule had proved it workable.203 The suggested alternative seemed to favor the United States, where copyright has a relatively short duration ;10 European and South American law would have granted American works lengthy protection abroad, ${ }^{211}$ while United States law abbreviated protection of foreign works here."1:

\section{Reservations and UCC's Effect on Prczious Agrecments}

Unlike Berne, UCC permits no reservations. ${ }^{213}$ Although the Conference realized that such a stipulation might make some nations hesitant to join, it felt that complete adherence was necessary to insure minimum standards of protection. ${ }^{214}$ In addition, Berne nations feared that some Lnion members might renounce its high standards and enforce only the less stringent protection afforded by UCC. ${ }^{215}$ Hence UCC specifies that the Berne Uniun shali

203. See note 103 supra; 2 Unesco Copyrigrt Bull 70-81 (No. 2-3 1949). The United States has the shortest fixed term, lasting at most fifty-six years. In Yugoslavia, protection endures after the death of the author, during the life of an unremarried spouse and until the author's youngest child reaches the age of twenty-five. Ilid.

204. UCC art. IV, § 4.

205. Ibid.

206. 17 U.S.C. $\$ \$ 245$ (Supp. 1952).

207. See UCC art. III, $\$ 5$.

208. Report of Rapporteur-General, supra note 165 , at 51 .

209. Id. at 51-2.

210. See authorities cited note 203 supra.

211. See 2 Uniesco Copyright Bulc 70-81 (No. 2-3 1949).

212. The dispute had limited significance. In the United States, only 11 percent of all original copyrights are in fact renewed. Evans, Copyright and the Public Intcrest, 2 Unesco Copyright Bull. 3, 10 (No. 1 1949). Also see Chafee, supra note 4, at 506-11. Only those concerned with musical works seem particularly interested in extending protection through renewal. Confidential Interview.

213. UCC art. XX; Report of Rapporteur-General, supra note 105, at 04-0.

214. Report of the Rapporteur-General, stipra note 105, at 64-6.

215. See id. at 62-3; UCC art. XVII. 
remain in full force among its members. ${ }^{216}$ To discourage any exodus from Berne, UCC provides that works originating in a nation which withdraws from the Union after January 1, 1951 (before final formulation of UCC) shall not enjoy protection in Berne countries. ${ }^{217}$

Although Berne was left in force to maintain high standards of protection, in at least one instance it undermines the protection guaranteed by UCC. Japan, a Berne member, has refused to accept revisions relating to the duration of the translation right. ${ }^{218}$ She remains bound by the 1886 Convention which allows free translation ten years after publication. ${ }^{210}$ Under UCC's requirement, a Japanese translator would have to compensate the author, no matter when he translated. ${ }^{220}$ Since Japan objected to the UCC provision, she signed the UNESCO Convention ${ }^{221}$ only when assured that she would have to apply it only to works from non-Berne countries. ${ }^{222}$ Thus, despite the fact that UCC prohibits reservations, Japan does not have to meet the Convention's standards in this respect.

UCC would leave inter-American arrangements in force. In case of conflict, UCC would prevail over present treaties, but yield to agreements signed after its adoption. ${ }^{223}$

\section{Effect of UCC on the United States}

\section{Protection of Americans Abroad}

UCC measures the rights of foreign authors by those vested in nationals of the country where protection is sought; by deferring so frequently to domestic legislation, the Convention makes little attempt to equate substantive protection granted in one country to that afforded in others. As a consequence, ratification by the United States would assure American authors of greater protection abroad than at home. Unlike the United States, all European and most Latin American nations protect an author's moral rights $\mathbf{2 2 4}$

216. UCC art. XVII; Appendix Declaration to art. XVII.

217. See authorities cited note 216 supra.

218. 1 LADAS $393 ; 2$ id. at 1054-6.

219. BERNe Convention of 1886 art. V.

220. See p. 1086 supra.

221. Japan was the last country to sign the treaty, doing so only two days before the treaty was closed for signatures. Communication to the YALE LAW Journal from Dr. Arpad Bogsch, Copyright Division, Unesco, dated March 31, 1953, in Yale Law Library. And see, UCC art. VII, § 1; 163 PurLISHeRs WeEkLY 197 (1953).

222. Report of Rapporteur-General, supra note 165, at 64-6. Technically, the 1886 ten-year translation provision is in force in Japan, but there seems to be considerable doubt whether or not Japan honors it. Ostertag, Report of the Principal Events in the Domain of Copyright from 1931 to 1937, DRort D'AUTEUR (July, 1937) (translated from the French by Gertrude Rosenstein).

223. UCC art. XVIII.

224. For a comparison of provisions on moral rights, see 2 UNESCO Coprugur BulL. 58-67 (No. 2-3 1949). 
and give composers considerable control over recordings and non-commercial uses of their music. ${ }^{225}$

Adopting UCC would not, of course, augment Americans' present rights in Berne countries. Since Berne remains in effect under UCC, publication in Canada might remain an open door to protection in Europe. But UCC would significantly increase protection granted to American authors in non-Berne regions-notably Latin America.220

\section{American Protection of Forcign Authors under UCC}

The substantive rights of foreigners in the United States would be confined to those which domestic law extends to native authors..27 Even though the United States currently offers less substantive protection than Imericans can get abroad, UCC would make it simpler for foreign authors to obtain . Imerican copyright. Publication with notice would still be required, but no further formalities could be imposed."-s The United States could no longer require that foreign works appearing in English be printed here, nor could it force a foreign author to register or deposit copies in the Copyright Uffice. ${ }^{210}$

225. See 2 id. at $84,86-8$.

226. For a discussion of the inadequacy of present protection in Latin America, sse pp. 1071-2 supra.

227. See p. 1085 stpra. A foreign author will receive only limited protection against damage to his reputation by alterations by movic, television, or radio comranics. See Curwood v. Affiliated Distributors, 233 Fed. 219 (S.D.N.Y. 1922) (motion fícture producer acquiring movie rights to use author's name and story did not acquire right to use author's name on different story; cnjoined); Rocder, The Doctrinc of Mural Right, 53 Harv. L. Rev. 554 (1940); note 95 supra. Also see cases collected in Xute, 23 A.L.R.2d 244 (1952).

If a foreign composer grants one American record company a license to record his copyrighted music, he must permit all others to do likewise, 17 C.S.C. $\$ 1$ (e) (Supp. 1952) ; Shilkret v. Ifusicraft Records, Inc, 131 F.2d 929 (2d Cir. 1942) (same fur unpublished music). Generally, see Dubin, Copyright Aspects of Sound Recordisgs, 25 Si. CALIF. L. Rev. 139 (1953).

Neither works of applied art nor choreographic creations are entitled to copyright under 17 U.S.C. $\$ 1$ (Supp. 1952). But see N.Y. Times, Jan. 11, 1953, § 2, p. 10, col. 1; N.Y. Times, Dec. $28,1952, \S 2$, p. 13, col. 5 , reporting issuance of a copyright for a dramatic dance sequence. The issue seems to remain very much in doubt Mirell, Legal Protection for Choreography, 27 N.Y.U.L. REv. 792 (1952). On the status of applice art, see Bernini, Protection of Designs: United States and Fronch Law, 1 Ass. J. Cossp. L. 133 (1952); Blunt, America Again Strizes for Recognition of Design Rights, 1 Ans. J. (x.s.) 392 (1946); Kelley, Design Patcuts and Copyrights: The Scope of Protection, 21 Geo. WASH. L. Rev. 353 (1953); Note, The Vestal Bill for the Copyright Registration of Designs, 31 CoL. L. Rev. 477 (1931); Note, Protecting the Artistic Aspects of Articles of Utility: Copyright or Desigr Patcut?, 66 HAsv. L. Rev. 877 (1953); Note, Copyright Protection in the Area of Scientific and Technical Works, 38 Iowa L. REv. 334 (1953).

228. See note 187 supra and accompanying text.

229. Ibid.; UCC art. III, $\$ 1$. For present United States formalities, see test at notes 2431 supra. 


\section{Desirability of American Ratification}

Some spokesmen strenuously oppose American participation in UCC. Several of their objections fail to comprehend the Convention's real effect on present protection. At least one commentator stands against ratification on the ground that UCC, by preventing Americans from reprinting communist publications without permission, might restrict the flow of information from Iron Curtain countries. ${ }^{230}$ But the Convention would require the United States to copyright only those works emanating from signatory nations. Communist ratification is unlikely; although some of the satellites joined Berne before they became communist, ${ }^{231}$ the U.S.S.R. has never participated in an international copyright organization. ${ }^{232}$ And to adhere to UCC, a nation must obligate itself to assure the foreign author of payment and of a "correct" translation of his work. ${ }^{233}$ Living up to such standards would interfere with current Soviet practices. ${ }^{234}$

Even if Russia joined UCC, the real stumbling block would continue to be communist censorship, not American copyright. So long as the Soviet regime controls the communist press, she would probably be glad to have news reports reprinted in the United States. ${ }^{235}$ Even if the U.S.S.R. wished to prohibit reproduction of Russian publications, she could not prevent the United States Government from reprinting. ${ }^{236}$ And UCC would not prevent American commentators from analyzing the content of communist publications. ${ }^{201}$

230. Warner, The UNESCO Universal Copyright Convention, [1952] Wis. L. REv. 493, 499-503.

231. The satellite nations which are members of Berne are: Bulgaria (1921), Hungary (1922), Poland (1920), Rumania (1927), and Czechoslovakia (1921). Drolt n'Aureur 1 (Jan. 15, 1953). But no satellite country has yet ratified the Brussels Revision of 1948, ibid., although Czechoslovakia, Hungary, and Poland attended the Conference at Brussels as accredited participants. U.S. State Dep't, Report of the United States Ousenvek Delegation to the Brussels Copyrught Conference-1948 \&-9 (1949).

232. 2 Unesco Copyright Bull. 152 (No. 4 1949).

233. See pp. 1085-6 supra.

234. See Chafee, supra note 4 , at 523.

235. The same is true for artistic works, such as plays or novels, which are distributed in the Soviet Union, and can therefore be assumed to have some propaganda value. And the Soviets would probably be overjoyed if their scholarly works in economics, sociology, political theory, and philosophy were widely read in this country. In addition, if someone here did reproduce a Russian book and sold copies to the public, it is unlikely that the Soviet author would bring suit in the United States to enjoin the infringement.

236. If the Federal Government republishes any type of information-artistic, scholar$1 y$, technical, or military-it cannot be sued as an infringer. Section 8 of the Copyright Code states: "The publication or republication by the Government, either separately or in a public document, of any material in which copyright is stbsisting shall not be taken to cause any abridgment or annulment of the copyright." 17 U.S.C. \& \& (Supp. 1952).

237. Under UCC, foreigners will receive the same protection against infringement that Americans receive in the United States. UCC art. II. The test of unfair use of or comment on, the copyright work of another is "whether or not so much as has been reproduced ... will materially reduce the demand for the original. If it has, the rights of 
Any Western observer in Russia could report whatever he learned about the state of the Soviet Union, without hindrance from UCC. In effect, the Convention permits the United States to keep its meager contact with the communist world.

A second argument is that the UNEsco plan would force the United States to repeal the manufacturing clause, thereby allowing publishers to cripple the American printing industry by patronizing lower-cost printers abroad. ${ }^{238}$ This argument does not seem valid. In the first place, UCC would not require total abolition of the clause; the United States could still require its own nationals to print their works domestically. ${ }^{239}$. And although the Convention would bind this country to copyright foreign works printed abroad, granting such protection would not significantly injure American printers. If the foreign publisher anticipates a large American demand for a look, he currently arranges to have it printed here, whether or not the manufacturing clause requires him to do so. ${ }^{240}$ While the cost of printing each copy declines as the number of copies increases, the cost of shipping each copy remains relatively uniform. ${ }^{241}$ Hence, when large lots are involved, printing in the

the owner of the copyright have been injuriously affected. . . . The reduction in demand ... must result from the partial satisfaction of that demand by the alleged iniringing production. A criticism of the original work, which lessened its money value by showing that it was not worth seeing or hearing could not give any right of action for infringement." Hill v. Whalen \& Martell, 220 Fed. 359, 360 (S.D.N.Y. 1914). Also sce Hovacu $125-6$.

238. Hearings, supra note 6 , at $69-\$ 2$.

239. The Convention does not limit the right of a signatory nation to impose conditions precedent to copyright on its own nationals. See pp. 10\$7-S supra.

Even if UCC did require total abolition of the manufacturing clause, Ameriean publishers would probably continue to have their printing done in this country. See statcment of R. L. Crowell, of Thomas Y. Crowell Co. in Hcarings, supra note 6, at G4: "So we sent the manuscript to Barcelona, having found out about a goosd printer there. . . . $[N]$ ot only could they not beat United States prices but ... it took them abuut as long to get the estimate to us as it would for us to get the whole bouk manuiactured and we haven't got the manuscript back yet. As far as we are concerncd, once is enuugil."

240. Testimony of Arthur E. Farmer, American Book Publishers Cuuncil in Hcarings, supra note 6, at 150-74. Mr. Farmer states: "A lot of Penguin bools, of course are public domain books. ... [W] ithin the last year Penguin of England has established a Penguin of Maryland and is now manufacturing the Penguin bouks for sale in this country. They are no longer, and they never were, able successfully to export the boolss to this country, so they have established an American branch and are manuiacturing in Maryland." Id. at 164. The same is true for scientific works which are rarely, if ever, pirated. Communication to the Yale Law Joursal from Warren Sullivan, John Wiley \& Sons, Inc., dated February 4, 1953, in Yale Law Library; and for sheet music, which is not subject to the manufacturing clause, see Hcarings, supra note 6 , at 187 . Also see 17 U.S.C. $\$ 16$ (Supp. 1952). It is unlikely that any printers would actually be thrown out of work by the abolition of the clause. See Memoranda Regarding Proluable Effets on the Printing Industry of Adoption of the Copyright Conastion, S. Dec. No. 99, 76th Cong., 1st Sess. (1939).

241. Hearings, stpra note 6 , at 181-5. 
United States is cheaper than printing extra copies in Europe and shipping them to this country. ${ }^{242}$

If the foreign publisher forsees only a limited demand in the United States, however, he will probably be unable to arrange for an American printing. 243 The manufacturing clause is designed to force him to print in the United States. $^{244}$ But English publishers, faced with such a situation, presently risk piracy by shipping copies into this country rather than pay American printing costs. ${ }^{245}$ Although conclusive evidence is unavailable, the foregoing analysis indicates that the manufacturing clause simply denies copyright to foreign authors without protecting the American printing trades against foreign competition. In any event, the United States could protect its printers through tariff legislation, without refusing to protect foreign works. ${ }^{240}$

A third objection to UCC is that United States ratification would serve only to bolster foreigners' protection here, without substantially enhancing American rights abroad. ${ }^{247}$ America, the argument runs, already enjoys excellent protection throughout the Berne Union. ${ }^{248}$ But UCC potentially assures protection in non-Berne countries as well. ${ }^{240}$ Furthermore, there is no guarantee that the United States will continue to bask in European protection if it refuses to accept the UNEsco Convention. ${ }^{250}$ Berne permits its members to deny copyright to works coming from a non-Berne nation which does not extend adequate protection to material originating in Berne countries. ${ }^{251}$ In the past, European nations have not invoked this provision principally because the United States seemed on the verge of joining Berne. ${ }^{202}$ Were this country to reject UCC, a compromise pointedly designed to appeal to the United States, ${ }^{258}$ Europe might understandably despair of ever securing approval of Berne's more demanding provisions. Then wholesale piracy could be

242. Id. at 177-85.

243. Id. at 164.

244. See pp. 1069-70 supra.

245. See Unwin, The Truth About Publishing 193-9, 269-80 (4th ed. 1946).

246. For an excellent discussion, suggesting that the General Agreement on Tariffs and Trade, if enacted, would supplant the manufacturing clause, see Note, The Mamfacturing Clause: Copyright Protection of the Foreigin Author, 50 CoL. L. REv. 686, 697 (1950). To the same effect, see Hearings before Committee on Foreign Affairs on International Trade Organtzation, HJ. Res. 236, 66-70, 519-20, 539-48, 715-17 (1950); Communication to the Yale Law Journal from Dr. Clair Wilcox, Professor of Economics, Swarthmore College, dated October 15, 1952, in Yale Law Library.

247. See Warner, The UNESCO Universal Copyright Convention, [1952] Wis. L. Rev. 493, 499-505.

248. Id. at 505 .

249. See text at note 265 infra.

250. Hearings, supra note 6, at 63, 88-99; Confidential communications to the YAL: LAW JOURNAL.

251. See p. 1079 supra.

252. See authorities cited note 124 supra.

253. See text at note 163 supra. 
expected to follow. ${ }^{254}$ Hence, failure to ratify may seriously prejudice American authors' rights in the Berne Union.

When the foregoing arguments against ratification are disregarded it becomes clear that the real choice is whether or not to curtail international piracy. Piracy has one distinct advantage; it promates wide dissemination of foreign works. On the other hand, its major drawback is that it deprives creators of potential income in an era in which most of them must sell their works to live. Publishers who pirate are not noted for dividing their profits with authors.

The ultimate question for resolution, then, is whether it is a sound policy to deprive authors of income from foreign sales. Some writers espouse international piracy on the ground that the prospect of a foreign market does not motivate authors to create; that they generally anticipate domestic sales only. ${ }^{255}$ Considering the volume of copyrightable materials presently flowing between countries, 250 this hypothesis is of questionable validity. Furthermore, failure to protect foreign works may stunt domestic authorship to some e::tent. Publishers, like those in nineteenth century America, ${ }^{2 s i}$ may prefer to pirate foreign material rather than pay royalties to native creators.

Regardless of how much it stimulates artistic production, international copyright protection can be defended on the ground that artists, whose efforts provide the world with so much enjoyment and enrichment, deserve maximum compensation. Although most creators might continue to produce even though ill-paid, a sound policy would assure them of something better.

"[N]ot long ago, a group of representatives ... endeavored to do away with copyright altogether. ... To such men as these, only junk fabricators, gadgeteers, tram operators, pop bottlers and the like are entitled to the best profit for their contribution to life. History will note the fact when history writes how American avarice held in open contempt all culture and all thought, decerebrated itself and so died headless."? 258

\section{CONCLUSION}

While UCC is probably acceptable to the bulk of American authors, 239 publishers, ${ }^{260}$ and representatives of the mass media, ${ }^{261}$ it is opposed by a

254. See authorities cited note 250 supra.

255. Warner, supra note 247 , at 505 .

256. For a description of the growth of American exports from $\$ 2,000,000$ in 1891 to over $\$ 50,000,000$ in 1950 , see Hcarings, supra note 6 , chart $B$, at 221 . And the number of translations made overseas has jumped since the end of World War II. Usiesco, Statistical Report on Book Production 1937-1950 Table 4A, 33 et scq. (1952). On the rise in British exports, see 163 Publishers WeEkLy 292, 1360 (1953).

257. See Carex, The International Copyright Question Considirco (1872);

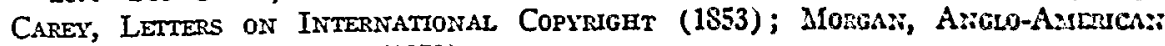
INTERNATIONAL COPYRtget (1879).

258. WruIE, Opus 21, p. 13 (1949).

259. Hearings, supra note 6 , at $10,102-108$.

260. Id. at 26,63 .

261. Id. at 89 et seq. 
small, but vociferous group of printers' unions ${ }^{262}$ and book manttfacturers. ${ }^{203}$ This opposition should not be allowed to prevail. American ratification will necessitate no harmful changes in domestic copyright law, ${ }^{264}$ nor will it put this country at a disadvantage in the Cold War. UCC's success will ultimately depend on the United States since most nations will probably condition their acceptances on American participation. ${ }^{265}$ UCC calls upon this country to assume leadership in the world cultural community.

262. Id. at $56,69,76,80$.

263. Id. at 35 .

264. The following changes in American law will be necessary: 1) repeal of $\S 16$, the manufacturing clause, as applied to books and periodicals written by non-resident aliens in English, 17 U.S.C. $\$ 16$ (Supp. 1952) ; 2) repeal of $\S 14$, giving the Register of Copyrights the power to demand copies for deposit from foreign authors, 17 U.S.C. $\$ 14$ (Supp. 1952); 3) repeal of $\S 1(\mathrm{e})$ insofar as it requires a special Presidential proclamation for protcction of mechanical reproductions, 17 U.S.C. $\S 1$ (e) (Supp. 1952) ; 4) repeal of the formalities of registration and notice, 17 U.S.C. $\$ \S 10,11$ (Supp. 1952).

265. Confidential communications to the YAlE LAw Journal. The treaty permits ratification by one country conditioned on the ratification by another. UCC, protocol $3, \S 1$. 